\title{
STRATEGI BERSAING SEKOLAH KRISTEN LENTERA AMBARAWA
}

\author{
Jubelina \\ Alumni Magister Manajemen Pendidikan Universitas Kristen Satya Wacana \\ Supramono \\ Magister Manajemen Pendidikan Universitas Kristen Satya Wacana \\ supramono@staff.uksw.edu
}

\begin{abstract}
ABSTRAK
Dunia pendidikan diperhadapkan dengan berbagai persaingan antar lembaga pendidikan yang terbilang sangat kompleks dan beragam. Kondisi persaingan tersebut dapat menjadikan lembaga pendidikan yang mampu bertahan menjadi unggul, namun bagi lembaga pendidikan yang tidak mampu bertahan akan mengalami penurunan. SMP Kristen Lentera, sebagai salah satu pendatang baru dalam dunia pendidikan juga mengalami kondisi tersebut. Oleh karena itu, timbul pertanyaan "Bagaimana strategi bersaing SMP Kristen Lentera Ambarawa?". Untuk mengetahui tentang strategi bersaing, dalam penelitian ini dijelaskan tentang tiga pendekatan strategi generik, yaitu keunggulan biaya, diferensiasi dan fokus. Hasil penelitian menunjukkan bahwa SMP Kisten Lentera Ambarawa menerapkan strategi diferensiasi untuk menghadapi persaingan antar lembaga pendidikan.Strategi ini dilakukan dengan menerapkan berbagai program yang berbeda dari sekolah lainnya di Ambarawa seperti Multiple Intelligences, Moving Class, Sekolah Lima Hari, Wasana Warsa Sekolah Kristen Lentera, Hari Budaya, Field Trip dan Parent Seminar. Untuk itu, saran bagi SMP Kristen Lentera dalam menjalankan strategi diferensiasi yaitu dapat melaksanakan program-program baru yang telah direncanakan seperti sablon dan pembuatan asesoris pada pelajaran Mulok, Bahasa Mandarin, klub matematika dan klub Kuark. Selain itu juga melakukan kegiatan sosial seperti pengobatan gratis dan pembagian sembako bagi orang kurang mampu di sekitar Ambarawa.
\end{abstract}

Kata kunci: strategi bersaing, keunggulan biaya, diferensiasi, fokus

\section{PENDAHULUAN}

Dewasa ini, dunia pendidikan diperhadapkan dengan persaingan antar lembaga pendidikan. Kondisi persaingan tersebut dapat menjadikan lembaga pendidikan yang mampu bertahan menjadi unggul, namun bagi lembaga yang tidak mampu bertahan akan mengalami penurunan dalam hal mutu pendidikan (Suti, 2011).

Kondisi nyata persaingan yang dihadapi lembaga pendidikan dapat kita lihat di berbagai daerah. Di Kota Malang pada tahun 2008 sekolah-sekolah swasta di daerah tersebut mulai merugi, bahkan beberapa sekolah akhirnya harus ditutup (www.nasional. kompas.com). Di Palembang, dari total 516 sekolah swasta di kota tersebut, sekitar 60 persen terancam tutup karena sulitnya persaingan antar sekolah (www.palembang news.com).

Kondisi persaingan dan berbagai permasalahan yang terjadi dalam dunia pendidikan juga dialami oleh Sekolah Kristen Ambarawa yang dikelola oleh Yayasan PSAK Semarang, yang sekarang berubah menjadi Sekolah Kristen Lentera. Persaingan yang terjadi tentunya dalam hal penerimaan siswa. Hal tersebut juga bahkan dialami oleh Sekolah 
Kristen Lentera setelah mengalami pergantian dari Sekolah Kristen Ambarawa. Namun, Sekolah Kristen Lentera mampu menunjukkan keberadaannya terus mengalami perkembangan khususnya pada tingkat pendidikan SMP meskipun tergolong sekolah yang baru. Hal ini ditunjukan melalui beberapa prestasi yang diraih seperti kelulusan 100 persen pada UN tahun 2010-2012, juara II Mapel Fisika dalam Olimpiade Sains tingkat Kabupaten Semarang, dan juara untuk beberapa kategori dalam Festival Seni dan Kreativitas Kabupaten Semarang (www. sekolah. lentera.org).

Prestasi yang dicapai SMP Kristen Lentera hingga saat ini jauh lebih baik dari sekolah sebelumnya. Pada masa SMP Kristen Ambarawa, prestasi yang diraih pada umumnya untuk bidang non akademik seperti voli dan atletik sedangkan untuk bidang akademik tidak terlalu nampak. Prestasi tersebut juga tidak mencapai pada tingkat Kabupaten dan Provinsi seperti yang berhasil diraih oleh SMP Kristen Lentera pada masa sekarang.

Selain itu, SMP Kristen Lentera juga menjadi salah satu sekolah yang banyak diminati oleh masyarakat, tidak hanya yang berasal dari Kecamatan Ambarawa saja, melainkan juga dari beberapa kecamatan di sekitarnya seperti Bawen, Banyubiru, Bandungan dan Tuntang.

Perkembangan yang terjadi pada SMP Kristen Lentera sebagai pendatang baru dalam dunia pendidikan, menunjukkan bahwa sekolah mampu menghadapi persaingan dengan sekolah-sekolah yang lain. Hal tersebut bahkan diakui oleh beberapa sekolah di Ambarawa, salah satunya yaitu dikemukakan oleh Wakasek Kesiswaan SMP Pangudi Luhur yang mengatakan, bahwa SMP Kristen Lentera sebagai sekolah baru terus mengalami perkembangan dan kemajuan.

Keberhasilan yang sejauh ini dapat diraih SMP Kristen Lentera tidak terlepas dari usaha dan kerja keras pihak sekolah yakni pengurus yayasan, guru dan staff yang terus mengupayakan berbagai cara untuk memperkenalkan SMP Kristen Lentera kepada masyarakat. Menurut Kepala SMP Kristen Lentera, salah satu cara yang dilakukan yaitu mengikutsertakan siswa dalam berbagai kegiatan yang mewakili sekolah. Cara yang dilakukan tersebut selain untuk memperkenalkan sekolah, juga dapat menjadi strategi bersaing sekolah untuk menghadapi sekolah lainnya.

Strategi bersaing merupakan upaya mencari posisi bersaing yang menguntungkan dalam suatu lembaga. Strategi bersaing bertujuan membina posisi yang menguntungkan dan kuat dalam melawan kekuatan yang menentukan persaingan dalam lembaga (Porter, 1992). Strategi bersaing telah banyak dijalankan pada perusahaan, perbankan, industri atau di dunia bisnis. Dunia pendidikan pun telah menjalankan strategi bersaing, akan tetapi penelitian sebelumnya yang membahas tentang hal tersebut masih terbatas. Sejauh ini, ditemukan beberapa penelitian sebelumnya yaitu penelitian yang dilakukan oleh Sulung (2010) tentang strategi bersaing Sekolah Teknologi Informasi Komunikasi. Hasil dari penelitian yang dilakukan menunjukkan bahwa dalam menghadapi persaingan sekolah tersebut harus menerapkan strategi fokus, baik terhadap biaya maupun diferensiasi.

Selain itu penelitian juga dilakukan Narjono (2011) tentang pengaruh kekuatan persaingan industri Pendidikan Tinggi terhadap strategi bersaing program S1 Manajemen pada PTS yang menunjukkan hasil hasil adanya pengaruh terhadap strategi bersaing yang telah dilakukan. Penelitian lainnya yaitu oleh Shofwan tentang analisis strategi bersaing dalam manajemen peningkatan mutu di SMK Negeri 4 Kota Malang. Hasilnya menunjukkan bahwa untuk mendapatkan keunggulan bersaing maka terdapat beberapa aspek yang dilakukan pada tahapan input, proses dan output. 
Dalam sumber lainnya disebutkan juga bahwa untuk meningkatkan daya saing sekolah maka dilakukan pemasaran jasa pendidikan (Wijaya, 2008). Selain itu, juga salah satu kunci keberhasilan dalam persaingan sekolah adalah manajemen pemasaran sekolah (Octavian, 2005). Sedangkan bagi perguruan tinggi dilakukan strategi bersaing untuk menarik peserta didik, strategi bersaing untuk mengembangkan proses pembelajaran dan strategi bersaing untuk menghilangkan batas (Sulistyawati, 2007).

Berdasarkan latar belakang tersebut, maka penelitian ini ingin mengungkap bagaimana strategi bersaing SMP Kristen Lentera? Mengingat belakangan ini banyak sekolah yang mengalami kemunduran khususnya sekolah swasta, akan tetapi tidak demikian bagi Sekolah Kristen Lentera yang terus mengalami perkembangan. Selain itu juga karena masih terbatasnya penelitian sebelumnya tentang strategi bersaing yang dilakukan di dunia pendidikan. Tujuan dari penelitian ini yaitu untuk mendeskripsikan strategi bersaing yang diterapkan SMP Kristen Lentera Ambarawa.

\section{TINJAUAN PUSTAKA}

\section{Strategi Bersaing}

Strategi bersaing merupakan upaya mencari posisi bersaing yang menguntungkan dalam suatu arena fundamental di mana persaingan berlangsung (Porter, 1992). Strategi bersaing yang efektif mencakup tindakantindakan menyerang (ofensif) ataupun bertahan (defensive) guna menciptakan posisi bertahan yang aman (defendable position).

Untuk menghadapi kondisi persaingan, terdapat tiga pendekatan strategi generik yang secara potensial akan berhasil mengungguli pesaing lainnya dalam suatu bidang yaitu keunggulan biaya menyeluruh, diferensiasi dan fokus (Porter, 2007). Strategi generik itu sendiri dipahami sebagai suatu pendekatan yang me- mungkinkan suatu lembaga untuk mendapatkan keunggulan kompetitif yang melebihi pesaing lainnya dalam suatu lingkup usaha (David, 2008).

KEUNGGULAN STRATEGIS

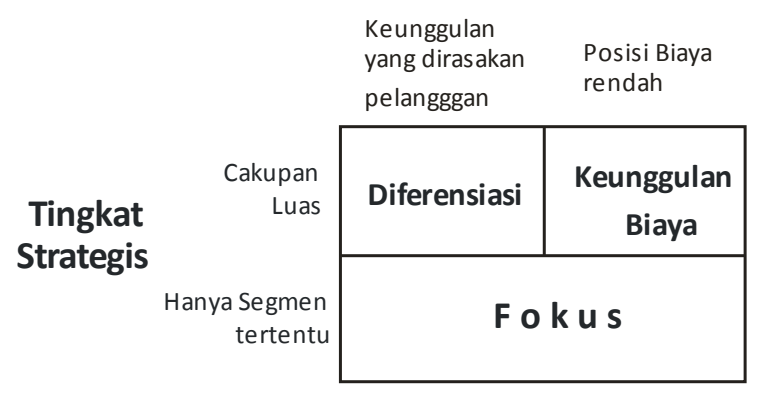

Gambar 1. Tiga Strategi Bersaing Generik (Porter, 2007)

\section{Keunggulan Biaya}

Dalam strategi keunggulan biaya, suatu lembaga berusaha menjadi produsen berbiaya rendah dalam bidangnya. Biaya rendah adalah kemampuan sebuah unit bisnis atau suatu lembaga untuk merancang, membuat, dan memasarkan sebuah produk sebanding dengan cara yang lebih efisien daripada pesaingnya (Hunger \& Wheelen, 2003). Dalam konteks lembaga pendidikan, keunggulan biaya yaitu strategi sekolah dalam mengefisienkan seluruh biaya operasionalnya sehingga menghasilkan jasa yang bisa dijual lebih murah dibandingkan pesaingnya. Hal utama bagi pihak sekolah adalah menawarkan jasa dengan harga yang sangat bersaing (Wijaya, 2008). Akan tetapi, dalam menjalankan strategi ini setiap sekolah perlu menetapkan harga yang paling tepat sehingga dapat memberikan keuntungan, baik untuk jangka pendek maupun untuk jangka panjang (Wijaya, 2008).

\section{Diferensiasi}

Diferensiasi yaitu strategi suatu lembaga dalam memberikan penawaran yang berbeda dibandingkan dengan penawaran yang diberikan pesaing (Porter, 1992). Dalam konteks lembaga pendidikan, sekolah berusaha 
untuk menjadi unik dalam bidangnya dengan sejumlah dimensi tertentu yang secara umum dihargai pelanggan. Dasar pemikiran strategi diferensiasi menuntut sekolah untuk memilih atribut, mempunyai jasa yang berkualitas ataupun fungsi yang bisa membedakan dirinya dari para pesaing. Misalnya persepsi terhadap keunggulan kerja, inovasi produk, pelayanan yang lebih baik, citra merek yang lebih unggul dan sebagainya (Wijaya, 2008). Mencapai diferensiasi akan berarti mengorbankan posisi biaya jika kegiatan yang diperlukan untuk menciptakan diferensiasi cukup mahal (Porter, 2007). Akan tetapi, dengan melakukan diferensiasi atau menjadi berbeda maka suatu lembaga memberikan sesuatu yang bernilai. Dengan kenyataan demikian, maka pelanggan akan bersedia untuk membayar dengan harga yang tinggi untuk produk atau jasa yang terdiferensiasi karena sesuatu yang ditawarkan oleh sekolah benar-benar berbeda dan unik serta tidak ada kemungkinan untuk ditemukan hal sejenis pada sekolah lainnya (Hitt dkk., 1997).

\section{Fokus}

Strategi generik yang ketiga adalah fokus. Pemilih strategi fokus memilih suatu bagian atau kelompok bagian tertentu dan menyesuaikan strateginya untuk melayani bagian atau kelompok segmen ini secara khusus (Porter, 1992). Dalam lembaga pendidikan, fokus yaitu strategi sekolah dalam menggarap satu target pasar tertentu.Hal ini pada umunya diawali dengan penentuan pangsa pasar oleh lembaga pendidikan (Purwanto, 2011). Lembaga pendidikan yang mapan dalam hal dana akan memilih pangsa pasar golongan atas. Lembaga pendidikan yang tidak terlalu mapan pada umumnya memilih golongan bawah dan jika memungkinkan memilih golongan menengah. Lebih lanjut tentang strategi fokus, Wijaya (2008) mengemukakan bahwa strategi ini biasanya juga dilakukan untuk jasa yang memang mempunyai karakteristik khusus. Misalnya, Sekolah Kristen yang hanya ditargetkan bagi siswa Kristiani sehingga semuanya disesuaikan dengan ajaran agama Kristiani meskipun tidak menutup kemungkinan untuk siswa yang beragama lainnya.

\section{Sekolah Kristen}

Sekolah Kristen adalah lembaga pendidikan formal usaha swasta yang didirikan atas dasar iman Kristen. Sekolah Kristen diselenggarakan atas dasar iman dan keyakinan Kristen, namun dapat memberikan masukan yang positif dan konstruktif bagi pengembangan kebudayaan bangsa karena sekolah Kristen berada di dalam negara dan diselenggarakan untuk kepentingan negara (Wirowidjojo, 2011).

Lebih lanjut tentang sekolah Kristen, Sairin (2011) mengemukakan bahwa sekolah Kristen adalah lembaga pendidikan sekolah yang me-nyelenggarakan pengajaran dan pendidikan umum dalam rangka pendidikan nasional. Sekolah Kristen terbuka bagi semua peserta didik tanpa membedakan jenis kelamin, suku, agama, ras, golongan, kedudukan sosial, dan tingkat kemampuan ekonomi serta menerima dasar, persyaratan, dan peraturan/tata tertib sekolah sesuai dengan hakikat lembaga pendidikan Kristen.

\section{Tujuan dan Fungsi Sekolah Kristen}

Kehadiran sekolah Kristen dalam dunia pendidikan memiliki tujuan untuk membantu berkembangnya seseorang atas dasar pandangan Kristen agar mencapai tingkat kedewasaan yang religius etis dan bertanggung jawab, sehingga dapat menjalankan tugas kedewasaannya dalam persekutuan keluarga, persekutuan agama, dan persekutuan negara serta mampu memenuhi fungsinya yang serasi sebagai anggota bangsa dan masyarakat(Wirowidjojo, 2011). Sekolah Kristen juga memiliki beberapa fungsi yaitu (Sairin, 2011): 
1. Fungsi kesaksian dan pelayanan, yaitu sebagai wahana untuk menyaksikan Injil Kristus serta memperkenalkan kehidupan Kristen.

2. Fungsi pendidikan dan pengajaran, yaitu mengikuti perkembangan ilmu pengetahuan, seni dan teknologi, mengkajinya dalam hubungannya dengan iman Kristen, mengkomunikasikannya dengan peserta didik.

3. Fungsi pembinaan, yaitu menolong dan membimbing peserta didik.

4. Fungsi pelayanan masyarakat, yaitu menghadirkan diri sebagai berkat bagi masyarakat.

\section{METODE}

Penelitian yang dilakukan dengan mengambil lokasi pada SMP Kristen Lentera di Ambarawa. Jenis data dikategorikan atas dua yaitu data primer dan data sekunder. Data primer diperoleh melalui wawancara, sedang data sekunder diperoleh melalui dokumen sekolah dan website sekolah berupa profil sekolah, jumlah penerimaan siswa, prestasi sekolah, program atau kegiatan yang ditawarkan sekolah dan fasilitas yang terdapat di SMP Kristen Lentera. Penyebaran kuesioner dilakukan bagi 11 orang guru sedangkan observasi dilakukan untuk mengamati aktivitas dan lokasi sekolah.

\section{HASIL PENELITIAN}

\section{Analisis Strategi Bersaing Sekolah Kristen Lentera}

Strategi bersaing merupakan upaya sekolah untuk menghadapi persaingan dengan cara memberikan berbagai hal yang terbaik guna memenuhi kebutuhan masyarakat. Berkaitan dengan hal tersebut, hasil penelitian menunjukkan bahwa SMP Kristen Lentera juga menjalankan strategi bersaing untuk menghadapi persaingan yang terjadi dalam dunia pendidikan. Untuk mengetahuinya secara rinci maka akan dijelaskan dalam ketiga pendekatan (keunggulan biaya, diferensiasi, fokus) dari strategi bersaing berikut ini, berdasarkan data yang diperoleh saat penelitian.

\section{Keunggulan Biaya}

Keunggulan biaya merupakan strategi sekolah dalam memberikan biaya yang murah kepada masyarakat bila dibandingkan dengan sekolah lainnya. Dalam hal ini setiap sekolah berupaya untuk menetapkan biaya yang tepat agar masyarakat dapat tertarik dan memilih sekolah tersebut.

Berkaitan dengan hal tersebut, hasil penelitian menunjukkan bahwa SMP Kristen Lentera telah berupaya untuk menetapkan biaya yang tepat dengan berbagai pertimbangan sehingga mendapatkan biaya pendidikan yang sesuai dengan kondisi SMP Kisten Lentera, meskipun tidak sepenuhnya tergolong murah. Rincian biaya pendidikan pada SMP Kristen Lentera dan juga beberapa sekolah swasta lainnya, ditunjukkan pada tabel 1 .

Biaya pendidikan SMP Kristen Lentera seperti terlihat dalam tabel 1 merupakan biaya yang berlaku hingga tahun pelajaran 2012/ 2013. Berkaitan dengan biaya pendidikan tersebut, hasil penelitian melalui wawancara dan juga penyebaran kuesioner mengungkapkan adanya berbagai pendapat dan penilaian yang dikemukakan oleh orang tua, guru, Kepala Sekolah dan pihak Yayasan Lentera Edukasi tentang mahal tidaknya biaya pendidikan yang ditetapkan oleh SMP Kristen Lentera.

Pendapat yang pertama dikemukakan Kepala SMP Kristen Lentera. Beliau mengatakan bahwa biaya pendidikan pada SMP Kristen Lentera tidak tergolong murah, namun juga tidak tergolong mahal. Dengan kata lain, biaya pendidikan pada SMP Kristen Lentera berada pada posisi menengah. Selain itu, biaya pendidikan pada SMP Kristen Lentera dapat juga dikatakan relatif. Bagi sebagian orang dapat dikatakan murah namun juga sebaliknya, tergantung dari penilaian dan kemampuan setiap orang. 
Tabel 1. Kewajiban Biaya Pendidikan di SMP Kristen Lentera dan SMP Swasta lainnya di Ambarawa

\begin{tabular}{llcc}
\hline \multicolumn{1}{c}{ Jenis } & \multicolumn{1}{c}{$\begin{array}{c}\text { SMP Kristen } \\
\text { Lentera }\end{array}$} & $\begin{array}{c}\text { SMP Pangudi } \\
\text { Luhur }\end{array}$ & $\begin{array}{c}\text { SMP Taman } \\
\text { Dewasa }\end{array}$ \\
\hline Uang SPP & Rp 100.000 & Rp 150.000 & Rp 70.000 \\
Rp 200.000/bln & Rp 200.000/bln & Rp 80.000/bln \\
Uang Kegiatan & Rp 125.000/thn & Rp 20.000/bln & - \\
Uang Tes & Rp 10.000/tes & - & Rp 100.000/tes \\
Tabungan Wajib & Rp 15.000/bln & Rp 25.000/bln & - \\
Uang Komite & Rp 4.000/bln & - & - \\
Uang Komputer & \multicolumn{1}{c}{-} & Rp 20.000/bln & - \\
\hline
\end{tabular}

Sumber: Kepala SMP Kristen Lentera, Kepala SMP Taman Dewasa, Administrasi SMP Pangudi Luhur

\section{Diferensiasi}

Diferensiasi merupakan strategi sekolah untuk dapat menjadi berbeda dengan sekolahsekolah lainnya. Hasil penelitian menunjukkan bahwa yang membedakan SMP Kristen Lentera dengan sekolah swasta lainnya di Ambarawa yaitu terletak pada ciri khas sekolah. Sebagai satu-satunya sekolah swasta Kristen untuk jenjang SMP di Kecamatan Ambarawa, SMP Kristen Lentera berupaya untuk mewujudkan ciri khasnya dengan menekankan pengenalan akan Tuhan Yesus kepada para siswa.

Untuk dapat lebih menekankan ciri khasnya sebagai sekolah yang didirikan atas dasar Kristen, SMP Kristen Lentera mengadakan berbagai kegiatan kerohanian yang dilakukan untuk menunjukkan ciri khasnya sehingga sesuai dengan Visi \& Misi Sekolah. Kegiatan tersebut yaitu ibadah untuk guru dan karyawan yang dilakukan setiap hari sedangkan untuk siswa diadakan ibadah rutin setiap bulan dan juga renungan pagi di setiap kelas untuk mengawali kegiatan belajar pada hari tersebut. Selanjutnya ibadah thanks giving day sebagai bentuk ungkapan syukur kepada Tuhan, yang diikuti oleh seluruh keluarga besar Sekolah Kristen Lentera.

SMP Kristen Lentera juga memiliki diferensiasi dari sekolah lainnya di sekitar
Ambarawa seperti kegiatan pembelajaran, hubungan sosial dengan masyarakat, pelayanan bagi semua pihak yakni siswa, guru, maupun orang tua siswa. Berbagai hal tersebut ditampilkan pada tabel 2.

\section{Fokus}

Fokus merupakan strategi sekolah dalam menentukan kelompok tertentu yang akan menjadi target atau sasarannya. Dalam strategi ini, pihak sekolah akan memberikan programprogram ataupun menawarkan biaya tertentu yang sesuai dengan kelompok masyarakat yang telah ditentukannya.

Berkaitan dengan strategi fokus, hasil penelitian menunjukkan bahwa dalam melaksanakan proses pendidikan ataupun dalam menghadapi persaingan di dunia pendidikan, SMP Kristen Lentera tidak berfokus pada kelompok masyarakat tertentu untuk menarik minat mereka terhadap sekolah. Keberadaan SMP Kristen Lentera di Kecamatan Ambarawa terbuka untuk menerima siswa dari berbagai latar belakang tanpa adanya batasan. SMP Kristen Lentera juga memiliki programprogram yang sasarannya ditujukan kepada masyarakat luas dan semua pihak yang ada di lingkungan Sekolah Kristen Lentera. 


\title{
Tabel 2. Diferensiasi SMP Kristen Lentera
}

\author{
NO PROGRAM \\ $1 \quad$ Multiple Intelligences \\ - Multiple Intelligences (MI) diterapkan sejak berdirinya Sekolah Kristen Lentera pada tanggal 1 Juli 2007. \\ - Tujuan menerapkan multiple intelligences (MI) agar dapat membantu siswa-siswi dalam menemukan \\ dan mengembangkan bakat atau kepintarannya. \\ - Pendekatan multiple intelligences (MI) telah berhasil menjadikan siswa-siswi SMP Kristen Lentera \\ berprestasi dalam berbagai bidang.
}

\section{Parent Seminar}

- Seminar bagi orang tua siswa dengan tema-tema tertentu seperti "Kerjasama Sekolah-Orangtua" dan "Sikap dan Kebiasaan Belajar Menghadapi Tantangan Abad 21".

- Pihak sekolah berkomitmen untuk terus membangun relasi yang dekat dengan orang tua/wali murid dan memberikan informasi yang bermanfaat bagi mereka.

- Kegiatan ini diselenggarakan dengan bantuan dari Direktur Eksekutif Sekolah Kristen Lentera dan kejasama dengan pihak lainnya seperti sekolah IPEKA Jakarta. Dalam kerjasama tersebut IPEKA mendatangkan AAS (Adobe A School) dari Jakarta.

3

\section{Moving Class}

- Program Moving Class mulai diterapkan di SMP Kristen Lentera sejak tahun pelajaran 2012/2013 dan belum dilakukan oleh sekolah lainnya di kecamatan Ambarawa.

- Pertimbangan sekolah menerapkan moving class yaitu untuk mengatasi masalah keterbatasan ruang kelas.

- Sekolah menyesuaikan antara ruang kelas yang ada dengan setiap mata pelajaran dan menyediakan fasilitas pendukung program moving class.

\section{$4 \quad$ Hari Budaya}

- Program Hari Budaya Sekolah Kristen Lentera dilaksanakan pada bulan Oktober dalam rangka memperingati Sumpah Pemuda dan bulan Bahasa.

- Kegiatan ini berupa Pawai Budaya yang diikuti oleh siswa dan guru dari semua jenjang pendidikan di Sekolah Kristen Lentera yang juga mengenakan pakaian adat dari berbagai daerah di Indonesia.

\section{Sekolah Lima Hari}

- Sekolah lima hari hanya diterapkan di SMP Kristen Lentera untuk Kecamatan Ambarawa. Sekolah dimulai pukul 07.25 dan berakhir pukul 14.30 .

- Sekolah mempertimbangkan kondisi siswa dan memberikan kesempatan untuk siswa memiliki waktu yang cukup di akhir pekan sehingga ketika kembali bersekolah di hari Senin lebih siap dan bersemangat.

\section{Wasana Warsa Sekolah Kristen Lentera}

- Wasana Warsa adalah kegiatan untuk menutup tahun ajaran yang telah selesai untuk semua jenjang pendidikan yang ada di Sekolah Kristen Lentera.

- Kegiatan diisi dengan ibadah, penampilan berbagai bakat dan talenta dari siswa Sekolah Kristen Lentera, serta pemberianpenghargaan dan piagam kepada 3 siswa peraih nilai tertinggi di setiap grade.

\section{$7 \quad$ Field Trip}

- Field Trip merupakan program SMP Kristen Lentera dan Sekolah Pelita Harapan International Lippo Village yang telah dilakukan sejak tahun 2011

- Siswa-siswa dari SKL dan SPH berkesempatan untuk belajar bahasa (Jawa dan Inggris), mengenal permainan daerah dan juga merasakan kehidupan masyarakat di desa seperti menanam padi, memancing dan berbelanja di pasar tradisional. 
Meskipun SMP Kristen Lentera terbuka untuk semua lapisan masyarakat tanpa adanya batasan untuk kelompok tertentu, akan tetapi hasil penelitian juga menunjukkan bahwa sebagian besar masyarakat yang memilih SMP Kristen Lentera berasal dari kalangan menengah ke bawah. Untuk hal tersebut, SMP Kristen Lentera berupaya untuk peduli dan memperhatikan siswa-siswi yang berasal dari kalangan bawah atau kurang mampu, khususnya dalam hal biaya pendidikan dengan cara memberikan beasiswa atau potongan SPP bagi siswa yang bersangkutan.

\section{Keunggulan biaya}

Biaya pendidikan pada SMP Kristen Lentera terdiri dari SPP, uang kegiatan, uang tes, tabungan dan uang komite. Apabila dibandingkan dengan biaya pada sekolah swasta lainnya di Ambarawa, maka terlihat perbedaan dimana biaya yang ditetapkan oleh SMP Kristen Lentera khususnya dalam hal SPP hampir sama besarnya dengan sekolah lainnya, bahkan lebih mahal. Sedangkan untuk biaya lainnya SMP Kristen Lentera lebih murah dibandingkan sekolah lainnya. Dengan demikian dapat dikatakan juga bahwa SMP Kristen Lentera tidak menetapkan biaya pendidikan yang murah secara menyeluruh karena ada biaya yang tergolong mahal, namun ada juga yang murah.

Kenyataan tersebut menjadikan SMP Kristen Lentera sebagai sekolah yang tidak tergolong murah dan juga menunjukkan bahwa SMP Kristen Lentera tidak menjalankan strategi keunggulan biaya. Sehingga pendapat yang dikemukakan oleh Hunger \& Whellen (2003) bahwa sebuah lembaga akan menjadi produsen berbiaya rendah atau menawarkan biaya paling rendah yang bersaing dengan sekolah lainnya tidak terbukti dilakukan oleh SMP Kristen Lentera. Dengan kata lain, dapat dikatakan juga bahwa berbagai pendapat yang mengemukakan bahwa SMP Kristen Lentera sebagai sekolah yang tidak murah merupakan hal yang benar.

\section{Diferensiasi}

SMP Kristen Lentera memiliki diferensiasi dalam hal ciri khasnya sebagai sekolah Kristen dan berbagai program yang dilaksanakan untuk siswa, guru, orang tua siswa maupun masyarakat. Untuk ciri khas sebagai sekolah Kristen, upaya sekolah dalam menekankan pengenalan akan Tuhan Yesus merupakan langkah yang tepat dan sesuai dengan tujuan sekolah Kristen dalam dunia pendidikan (Wirowidjojo, 2011) yaitu membantu berkembangnya seseorang atas dasar pandangan Kristen agar mencapai kedewasaan yang religious dan bertanggungjawab. Dengan demikian, maka SMP Kristen Lentera dapat menunjukkan bahwa SMP Kristen Lentera tidak hanya dikenal sebagai satu-satunya sekolah Kristen di Kecamatan Ambarawa, tetapi juga benar-benar mampu mewujudkan tujuan sekolah Kristen.

Diferensiasi lainnya dari SMP Kristen Lentera yaitu berbagai program yang dijalankan oleh Yayasan Lentera Edukasi maupun oleh SMP Kristen Lentera. Berbagai program tersebut menunjukkan bahwa pihak sekolah mengambil langkah yang tepat karena sekolah berupaya untuk memenuhi kebutuhan semua pihak yang berada di lingkungan SMP Kristen Lentera dan selalu mencoba memberikan pelayanan yang terbaik untuk kemajuan dan perkembangan sekolah. Tindakan sekolah ini sesuai dengan yang dikemukakan dalam salah satu sumber (staff.uny.ac.id) bahwa untuk dapat bersaing maka sebuah lembaga pendidikan perlu untuk memperhatikan faktor kebutuhan masyarakat. Ketika sekolah mampu untuk terus memberikan yang terbaik bagi masyarakat maka sekolah akan mampu mempertahankan dan meningkatkan minat masyarakat akan sekolah. 


\section{Fokus}

Hasil penelitian menunjukkan bahwa SMP Kristen Lentera tidak memiliki fokus pada kelompok masyarakat tertentu untuk menarik minat mereka terhadap sekolah. Dengan kata lain SMP Kristen Lentera terbuka kepada masyarakat dari berbagai kalangan dan wilayah. Langkah yang diambil oleh pihak sekolah ini berbeda dengan pendapat Porter (1992) bahwa dalam menjalankan strategi fokus setiap sekolah akan terlebih dahulu memilih atau menentukan kelompok tertentu dan melayani kelompok tersebut dengan berbagai fasilitas dan program yang telah disediakan. Oleh karena itu maka dapat dikatakan bahwa SMP Kristen Lentera merupakan sekolah yang tidak menjalankan strategi fokus.

Kebijakan sekolah untuk tidak memilih strategi fokus mungkin disebabkan karena keberadaan sekolah yang baru berdiri selama enam tahun dan masih berada dalam tahap memperkenalkan keberadaan sekolah kepada masyarakat luas. Ketika keberadaan SMP Kristen Lentera nantinya telah dikenal secara luas oleh masyarakat, maka pihak sekolah dimungkinkan untuk memilih fokus mereka.

Keputusan sekolah untuk tidak memilih strategi fokus merupakan suatu langkah yang tepat bagi pihak sekolah.Hal ini mungkin disebabkan karena pihak sekolah sendiri tidak ingin adanya batasan dan perlakuan yang berbeda terhadap kelompok tertentu.Pihak SMP Kristen Lentera ingin memberikan kesempatan kepada semua masyarakat untuk menikmati pendidikan seperti beberapa Misi dari sekolah yaitu mengembangkan sistem edukasi dan mengajak masyarakat untuk membangun diri.

\section{KESIMPULAN}

Berdasarkan penelitian yang telah dilakukan maka dapat disimpulkan bahwa, SMP Kisten Lentera Ambarawa menerapkan strategi diferensiasi dengan menjalankan berbagai program yang berbeda dari sekolah lainnya di Ambarawa antara lain Multiple Intelligences, Moving Class, Sekolah Lima Hari, Wasana Warsa Sekolah Kristen Lente-ra, Hari Budaya, Field Trip dan Parent Seminar. SMP Kristen Lentera tidak termasuk sekolah yang menjalankan strategi keunggulan biaya rendah karena berada pada posisi menengah dalam hal biaya pendidikan. SMP Kristen Lentera juga tidak menjalankan strategi fokus karena memiliki target yang luas dan memberikan kesempatan kepada semua masyarakat untuk menjadi bagian dari SMP Kristen Lentera.

\section{SARAN}

Berdasarkan hasil penelitian, maka terdapat beberapa rekomendasi untuk Sekolah Kristen Lentera dan juga penelitian mendatang:

1. Bagi Kepala SMP Kristen Lentera Kepala SMP Kristen Lentera diharapkan dapat melaksanakan program-program baru di SMP Kristen Lentera seperti sablon dan pembuatan asesoris pada pelajaran Mulok, program Bahasa Mandarin, klub matematika, klub Kuark dan program dalam bentuk kegiatan sosial seperti pengobatan gratis, pembagian sembako dan pemberian pakaian bekas layak pakai bagi orang yang kurang mampu di sekitar Ambarawa.

2. Bagi Yayasan Lentera Edukasi

Pengurus Yayasan Lentera Edukasi diharapkan dapat bekerjasama dengan Fakultas Psikologi dan pihak lainnya yang paham tentang penerapan Multiple Intelligences, untuk membantu dalam mengukur dan mengetahui kecerdasan setiap siswa serta membekali dan membimbing guru-guru untuk menerapkan Multiple Intelligences dalam proses pembelajaran.

3. Bagi Penelitian Mendatang

Penelitian mendatang diharapkan dapat melakukan analisis SWOT untuk mengetahui kekuatan, kelemahan, peluang dan 
ancaman sekolah juga letak strategi sekolah. Sehingga dengan demikian akan diketahui apakah strategi diferensiasi yang telah dilakukan SMP Kristen Lentera sudah tepat dan sesuai hasil analisis SWOT ataukah sebaliknya. Selain itu, penelitian mendatang diharapkan dapat membahas secara mendalam tentang dinamika pergantian Sekolah Kristen Ambarawa menjadi Sekolah Kristen Lentera sehingga dapat diketahui secara rinci pihak yang terlibat, proses pergantian sekolah, perubahan manajemen dan kepemimpinan dari kedua sekolah dan hal lainnya yang berkaitan dengan pergantian kedua sekolah tersebut.

\section{DAFTAR PUSTAKA}

David, Fred R. 2008. Manajemen Strategis: Konsep, Edisi 10. Jakarta: Salemba

Hitt, M. A., Ireland, R. D., Hoskisson, R. E. 1997. Manajemen Strategis: Menyongsong Era Persaingan Dan Globalisasi. Jakarta: Erlangga.

Hunger, David. \& Wheelen, Thomas L. 2003. Manajemen Strategis. Yogyakarta: Andi.

Narjono, Arijo Isnoer. 2011. Pengaruh Kekuatan Persaingan Industri Pendidikan Tinggi Terhadap Strategi Bersaing Program S1 Manajemen Pada PTS. Humaniora, Vol 8 No.1 Juni: 27-32.

Octavian, Henry Sumurung. 2005. Manajemen Pemasaran Sekolah sebagai Salah Satu Kunci Keberhasilan Persaingan Sekolah. Jurnal Pendidikan Penabur - No.05/ Th.IV/ Desember.

Porter, Michael. S. 1992. Keunggulan Bersaing; Menciptakan dan Mempertahankan Kinerja Unggul. Jakarta: Erlangga.

. 2007. Strategi Bersaing (Competitive Strategy): Teknik Menganalisis Industri dan Pesaing. Tangerang: Karisma Publishing Group.
Purwanto, N. A. 2011. Strategi Bersaing Dalam Bisnis Pendidikan. Jurnal Manajemen Pendidikan, No. 01/Th VII/ April.

Sairin, Weinata. 2011. Identitas dan Ciri Khas Pendidikan Kristen di Indonesia: Antara Konseptual \& Operasional. Jakarta: BPK Gunung Mulia.

Sulistyawati, Sri. 2007. Strategi Perguruan Tinggi Dalam Menghadapi Persaingan Global. Jurnal Madani, Vol.8, No.3, Juni.

Sulung, Alfianto Akbar. 2010. Strategi Bersaing Sekolah Teknologi Informasi Komunikasi (Studi Kasus: SMK Muhammadiyah 1 Samarinda). Diunduh 22 Januari 2013 dari www.library.binus.ac.id.

Suti, Marus. 2011. Strategi Peningkatan Mutu Di Era Otonomi Pendidikan. Jurnal MEDTEK, Volume 3 Nomor 2.

Wijaya, David. 2008. Pemasaran Jasa Pendidikan Sebagai Upaya untuk Meningkatkan Daya Saing Sekolah. Jurnal Pendidikan Penabur- No.11/Tahun ke7/Desember.

Wirowidjojo, R.S. 2011. "Identitas dan Ciri Khas Sekolah Kristen di Indonesia" dalam Sairin, Weinata. 2011. Identitas dan Ciri Khas Pendidikan Kristen Di Indonesia: antara Konseptual \& Operasional. Jakarta: BPK Gunung Mulia.

\section{Sumber Lainnya:}

Irawati, Dahlia. Sekolah-sekolah Swasta Mulai Bangkrut. Sumber: www.nasional. kompas. com. Dipublikasi 17 Juli 2008, diunduh 24 April 2013.

60 Persen Sekolah Swasta Terancam Tutup. www.palembangnews.com., diunduh 24 April 2013.

www.sekolah.lentera.org 